\section{Impact of Fungicide Program and Powdery Mildew Resistance in Three Varieties of Pumpkin}

\author{
Timothy Coolong ${ }^{1,3}$ and Kenneth Seebold ${ }^{2}$
}

AdDitionAl INDEX wORDs. Sphaerotheca fuliginea, Podosphaera xanthii, Cucurbitaceae, Cucurbita pepo

SuMMARY. The effects of fungicide program and varietal resistance on the development of cucurbit powdery mildew [PM (Podosphaera xanthii)] in pumpkin (Cucurbita pepo) were tested in 2009 and 2010 in Lexington, KY. Three fungicide programs consisted of a no-fungicide control, low input (chlorothalonil), and high input (chlorothalonil alternated with myclobutanil) were applied to three varieties of pumpkin with different levels of cucurbit PM resistance. Varieties tested were Howden, Aladdin, and Camaro, which had no, moderate, and high levels of cucurbit PM resistance, respectively. There were no significant variety by fungicide program interactions for yield, number fruit per acre, and average fruit weight in both years. In 2009 and 2010, variety significantly affected yield. Yield increases corresponded to the level of cucurbit PM resistance. The high-resistance variety, Camaro, had the greatest yields in both years, while Howden, with no PM resistance, had the lowest yields. In 2010, yield significantly increased with the intensity of fungicide program. With the exception of cull percentage in 2009 , there were no fungicide program by variety interactions for yield parameters. In both years, $\mathbf{P M}$ disease severity, characterized by the area under the disease progress curve (AUDPC), was lowest on 'Camaro' and highest on 'Howden'. In 2009, unsprayed 'Camaro' had similar AUDPC values as 'Aladdin' and 'Howden' treated with lowor high-input fungicide programs. In 2010, unsprayed 'Camaro' had less disease than 'Aladdin' or 'Howden' that had received the high-intensity fungicide program. These results suggest that yields can be maintained with a minimal fungicide program when using a variety with high cucurbit PM resistant in some environments. A high-input fungicide program may be necessary to maintain yields of varieties with low cucurbit PM resistance.

$\mathrm{P}$ umpkins are an important crop in the United States with $\approx 50,200$ acres planted in 2010 representing a total value of $\$ 116$ million [U.S. Department of Agriculture (USDA), 2011]. Illinois is the most significant pumpkin producing state with over 15,000 acres planted for processing and ornamental markets during fall months (USDA, 2011). About 1400 acres of pumpkins were planted in Kentucky in 2010, making them the second most planted vegetable behind sweet corn (Woods, 2010). Most pumpkins in Kentucky are grown as ornamentals for holiday markets such as Halloween and Thanksgiving.

Pumpkins are generally considered to be a low-input crop compared with many other vegetables in terms of production costs and management level (Woods, 2008). However, cucurbit PM

${ }^{1}$ Department of Horticulture, N-318 Agr. Sciences North, University of Kentucky, Lexington, KY 40546 ${ }^{2}$ Department of Plant Pathology, 205 Plant Science Building, University of Kentucky, Lexington, KY 40546

${ }^{3}$ Corresponding author. E-mail: timcoolong@uky.edu. is generally considered one of the most important diseases of cucurbits (Zitter et al., 1996) and poses a serious constraint to the production of pumpkins in Kentucky. Cucurbit PM can affect leaves, petioles, and stems with tissue turning chlorotic, then necrotic, resulting in premature senescence of leaves (Koike et al., 2007). Loss of photosynthetic area results in premature ripening of fruit and a loss of quality and yield. Because of the presence of necrotic tissue, plants infected by PM may be predisposed to infection by saprophytic pathogens as well (Perez-Garcia et al., 2009). Cucurbit $\mathrm{PM}$, an obligate parasite, can be introduced from greenhouse-grown cucurbits or on wind currents that can carry conidia long distances during the growing season (Koike et al., 2007). Because of these factors, PM is an annual pest of cucurbit crops in Kentucky (Bachi et al., 2010).

Control of PM in pumpkin is achieved through regularly scheduled fungicide applications during the growing season. Programs typically consist of protectant fungicides with broad modes of action applied early in the season, progressing to compounds with specific modes of action and improved effectiveness once PM has been confirmed. The development of resistance of PM, particularly to those compounds with specific modes of action, has resulted in a loss of management tools for growers (McGrath, 2006). Cucurbit PM has demonstrated the ability to develop fungicide resistance dating back to 1967 when resistance to the fungicide benomyl was documented (Schroeder and Provvidenti, 1969). More recently, resistance of PM to sterol biosynthesis inhibitor (SBI) and strobilurin fungicides (quinone outside inhibitors) has been documented (McGrath and Shishkoff, 2003; Wyenandt et al., 2008, 2010). Once a powerful tool for controlling PM in pumpkin, strobilurins are now largely considered ineffective because pathogen resistance to this class is qualitative. In the case of SBI fungicides, resistance is quantitative and results in reduced sensitivity rather than total insensitivity (Lebeda et al., 2010). Thus, strains of cucurbit PM tend to be only moderately resistant to SBI compounds in the United States. The development of $\mathrm{PM}$ resistance to certain fungicides

\begin{tabular}{llll}
\hline $\begin{array}{l}\text { Units } \\
\begin{array}{l}\text { To convert U.S. to SI, } \\
\text { multiply by }\end{array}\end{array}$ & U.S. unit & SI unit & $\begin{array}{l}\text { To convert SI to U.S., } \\
\text { multiply by }\end{array}$ \\
\hline 0.4047 & acre $(\mathrm{s})$ & $\mathrm{ha}$ & $2.471 \mathrm{l}$ \\
100 & $\mathrm{Bar}$ & $\mathrm{kPa}$ & 0.01 \\
112.0851 & $\mathrm{cwt} / \mathrm{acre}$ & $\mathrm{kg} \cdot \mathrm{ha}^{-1}$ & 0.0089 \\
0.3048 & $\mathrm{ft}$ & $\mathrm{m}$ & 3.2808 \\
9.3540 & $\mathrm{gal} / \mathrm{acre}$ & $\mathrm{L} \cdot \mathrm{ha}^{-1}$ & 0.1069 \\
2.54 & inch $(\mathrm{es})$ & $\mathrm{cm}$ & 0.3937 \\
0.4536 & $\mathrm{lb}$ & $\mathrm{kg}$ & 2.2046 \\
1.1209 & $\mathrm{lb} / \mathrm{acre}$ & $\mathrm{kg} \cdot \mathrm{ha}^{-1}$ & 0.8922 \\
70.0532 & $\mathrm{Oz} / \mathrm{acre}$ & $\mathrm{g} \cdot \mathrm{ha}^{-1}$ & 0.0143 \\
1 & $\mathrm{ppm}$ & $\mathrm{mg} \cdot \mathrm{L}^{-1}$ & 1 \\
6.8948 & $\mathrm{psi}$ & $\mathrm{kPa}$ & 0.1450 \\
$\left({ }^{\circ} \mathrm{F}-32\right) \div 1.8$ & ${ }^{\circ} \mathrm{F}$ & ${ }^{\circ} \mathrm{C}$ & $\left(1.8 \times{ }^{\circ} \mathrm{C}\right)+32$
\end{tabular}


may lead to growers relying on multisite inhibitor [Fungicide Resistance Action Committee (FRAC) code M] fungicides, which are less likely to promote resistance but may also give less than complete control of PM (McGrath, 2001). To remain competitive, growers also rely on pumpkins with resistance to cucurbit PM.

Resistance to PM is naturally occurring in several cucurbit species, though not in pumpkin (Cohen et al., 2003). However, resistance to cucurbit PM has been bred into pumpkin through interspecific hybridization using closely related wild okeechobee gourd (Cucurbita okeechobeensis) and cultivated squash (Cucurbita moschata) species (Cohen et al., 2003). Cucurbit PM-resistant pumpkin varieties were first commercialized in the late 1990 s (Keinath and DuBose, 2000). Resistance to cucurbit PM is believed to be conferred by a single incompletely dominant gene, though several recessive resistance genes in melons have also been characterized (Cohen et al., 2003; Jahn et al., 2002). Pumpkin varieties are generally marketed as tolerant or resistant if they are heterozygous or homozygous, respectively, for this gene. With the introduction of PMresistant pumpkin varieties, there have been numerous field trials at many sites across the United States, documenting levels of resistance and tolerance (Coolong and Seebold, 2008, 2009; James and Stevenson, 2005, 2006; McGrath and Davey, 2006). Pumpkins trialed generally could be categorized in one of three categories: susceptible (nonresistant), those varieties having tolerance or moderate resistance, and those that are considered highly resistant by comparisons in variety evaluations (Coolong and Seebold, 2008, 2009 ). With the continued introduction of varieties with a level of inherent resistance, it could be possible for growers to reduce fungicide inputs needed to manage cucurbit PM. The combination of variety resistance and a reduced input fungicide program could help reduce grower costs. Importantly, the reduced use of high-risk fungicides may help to decrease the chances for fungicide resistance development in cucurbit PM (McGrath, 2004).

McGrath and Davey (2006) reported differences in PM severity when evaluating several cultivated and experimental pumpkin varieties in a single reduced fungicide program. This reduced input program consisted of applying chlorothalonil (FRAC group M5) with myclobutinil (FRAC group 3 ) or quinoxyfen (FRAC group 13). Cushman et al. (2007) reported that using a fungicide program as opposed to a no-fungicide control increased yield in 'Lil Goblin' pumpkin regardless of spray schedule intensity. Wyenandt et al. (2008) evaluated 'Howden' (no resistance) and 'Magic Lantern' (moderate resistance) under five different fungicide programs ranging from protectant fungicides only to FRAC code-specific groupings of chemicals to monitor the development of cucurbit PM resistance to groups of fungicides. In that study, there were no variety by fungicide program interactions when testing for severity of cucurbit PM; however, a high (homozygous)-resistance variety was not trialed. More information is necessary to assess the impact of host resistance to $\mathrm{PM}$ and the possible interaction with fungicide programs to adequately manage this disease. The objectives of this trial were to determine the effects of variety PM resistance (none, moderate resistance, high resistance) and fungicide program (none, reduced input, intensive) on pumpkin yield and cucurbit PM severity.

\section{Materials and methods}

This study was conducted in the summer and fall of 2009 and 2010 at the University of Kentucky Horticulture Research Farm in Lexington (lat. $38^{\circ} 3^{\prime} \mathrm{N}$, long. $84^{\circ} 30^{\prime} \mathrm{W}$ ). The soil was a Maury silt loam series. The pumpkin varieties evaluated in this trial were Howden (Seedway, Elizabethtown, PA), Aladdin (Harris Moran, Modesto, CA), and Camaro (Hollar Seeds, Rocky Ford, CO), which had no, moderate, and high resistance to cucurbit PM, respectively. Resistance levels were determined in a previous trial (Coolong and Seebold, 2008). Pumpkins were seeded into 128-cell trays filled with soilless media (Pro-Mix BX; Premier Tech, Riviere-du-Loup, QC, Canada) on 1 June 2009 and 7 June 2010. Seedlings were greenhouse grown with temperature set points of $28^{\circ} \mathrm{C}$ day $/ 20^{\circ} \mathrm{C}$ night. Plants were watered daily as needed and fertilized weekly with a $150 \mathrm{mg} \cdot \mathrm{L}^{-1}$ nitrogen $(\mathrm{N})$ solution $(20 \mathrm{~N}-$ 4.4P-16.6K; Scotts, Marysville, $\mathrm{OH}$ ). Seedlings were transplanted into field plots on 30 June 2009 and 15 July
2010. Plants were transplanted using a mechanical transplanter (model 1000; Mechanical Transplanter Co., Holland, MI) into raised beds. Raised beds were about 8 inches tall and 28 inches across at the top. Beds were spaced on 10- or 8-ft centers in 2009 and 2010, respectively. Transplants were spaced $4 \mathrm{ft}$ within rows with two plants in each transplanting hole. Each plot consisted of 10 plants (five hills), and plots were separated by $12 \mathrm{ft}$ within rows. Plots were arranged in a strip-plot design with fungicide treatments as main plots and variety as subplot. The whole plot factor was organized in a randomized complete block design with varieties completely randomized within each strip. Each fungicide treatment was replicated four times with each variety replicated four times within each fungicide treatment for a total of 36 treatment plots. Untreated rows of an experimental selection, 'ACX 7302' (Abbott and Cobb, Feasterville, PA), previously determined to be highly susceptible to cucurbit PM (Coolong and Seebold, 2008) were planted between every other treatment row to ensure an even distribution of inoculum throughout the experimental plots.

Single lines of drip irrigation tubing (12-inch emitter spacing, 0.47 gallon/min per $100 \mathrm{ft}$ Aqua-Traxx; Toro, El Cajon, CA) were placed on the surface of each bed to provide supplemental water. Tensiometers (12-inch; Irrometer Co., Riverside, CA) were placed in each row and monitored to determine irrigation frequency. Irrigations were initiated when the tensiometers reached about $-60 \mathrm{kPa}$ and ended at about $-10 \mathrm{kPa}$. Preplant fertility (19N-8.3P-15.8K; Southern States Cooperative, Richmond, VA) was applied at a rate of $70 \mathrm{lb} /$ acre during the formation of raised beds. About 4 weeks after transplanting, plots were fertilized with a broadcast application of ammonium nitrate at a rate of $50 \mathrm{lb} /$ acre of $\mathrm{N}$. Clomazone (Command $3 \mathrm{ME}$; Helena Chemical Co., Collierville, TN) herbicide was applied to areas between plots. Withinrow spaces were hand cultivated as needed after vines began to spread between rows. Imidacloprid (Admire Pro; Bayer Crop Science, Research Triangle Park, NC) was applied at planting and permethrin (Pounce; FMC Chemicals, Philadelphia, PA) applied at 8 and 10 weeks after transplanting to control 
squash bug (Anasa tristis), striped cucumber beetle (Acalymma vittata), and spotted cucumber beetle (Diabrotica undecimpunctata). In 2009 , dimethomorph (Acrobat 50 WP; BASF, Research Triangle Park, NC), which does not have activity against cucurbit PM, was applied $(2.6 \mathrm{oz} /$ acre) twice during the season on the basis of weather conditions to protect against cucurbit downy mildew (Pseudoperonospora cubensis). In 2010, no additional fungicides, outside of treatment fungicides, were used. All chemicals were applied according to labeled rates.

Two fungicide programs, low and high input, were initiated when symptoms were first observed in the disease susceptible border rows. In 2009, the low-input program consisted of spraying chlorothalonil (Bravo WeatherStik; Syngenta, Greensboro, NC) at a rate of $1.5 \mathrm{lb} /$ acre on a $10-\mathrm{d}$ schedule $(8$ Aug., 19 Aug., 30 Aug., and 11 Sept. 2009). The high-input program in 2009 consisted of applying myclobutanil (Nova 40W; Dow AgroSciences, Indianapolis, IN) applied at a rate of $2 \mathrm{oz} /$ acre alternating with chlorothalonil ( $1.5 \mathrm{lb} /$ acre $)$ on a $7-\mathrm{d}$ schedule (8 Aug., 15 Aug., 22 Aug., 30 Aug., and 11 Sept. 2009). In 2010, the low-input program consisted of spraying chlorothalonil (Initiate; Loveland Chemical, Greely, $\mathrm{CO}$ ) at a rate of $1.5 \mathrm{lb} /$ acre every $10 \mathrm{~d}$ (16 Aug., 27 Aug., and 6 Sept. 2010). In 2010, the high-input program consisted of spraying myclobutanil (Rally 40 WSP; Dow AgroSciences) at a rate of $2 \mathrm{oz} /$ acre alternated with chlorothalonil (1.5 $\mathrm{lb} / \mathrm{acre}$ ) on the same 10-d schedule as the low-input program. Applications were made with a carbon dioxide powered backpack sprayer equipped with a three-nozzle hand boom fitted with hollow-cone nozzles (TX-18; Tee-Jet, Wheaton, IL) on 20-inch spacing. Application volume was equivalent to $40 \mathrm{gal} /$ acre, and sprayer pressure was 48 psi.

In 2009 , baseline severity of cucurbit PM was estimated on 29 July and cucurbit PM evaluation continued on a 7- to 11-d schedule beginning on 15 Aug. and concluded on 18 Sept. 2009. In 2010, baseline cucurbit PM evaluations were conducted on 23 July, resumed on 17 Aug., and continued on an 8-d schedule until 10 Sept. 2010. The upper and lower canopies of plants were separately evaluated using a $0-5$ scale, where
$0=$ no symptoms, $1=1 \%, 2=1 \%$ to $10 \%, 3=11 \%$ to $30 \%, 4=31 \%$ to $60 \%$, and $5=61 \%$ to $100 \%$ of the leaf area of the upper or lower canopy with symptoms of PM (Canaday et al., 2009). There were four ratings taken of the upper and lower canopies (eight in total) in each plot at each evaluation. The average ratings for each plot were converted to percent diseased leaf area (DLA) using the following transformation: $[1.5625-(5.625 \mathrm{X})+$ (5.0625X2)], where $\mathrm{X}=$ assigned rating (C. Canaday, personal communication). Percent DLA values for PM were used to calculate areas under disease progress curves to assess seasonlong severity of disease (Shaner and Finney, 1977). Pumpkins were harvested on 7 Oct. 2009 and 3 Oct. 2010 weighed and graded as marketable or unmarketable fruit. Fruit that were malformed, poorly colored, or had diseased or broken stems were culled.

Weather data were obtained from an on-farm weather station (Kentucky Mesonet, Fayette County Station, Lexington, KY) that recorded environmental variables every minute and provided hourly averages (University of Kentucky, 2011).

Yield and disease data were compared using PROC GLM in SAS (version 9.1; SAS Institute, Cary, NC) for a split-plot design where the whole plot factor (fungicide treatment) was arranged as a randomized complete block design with random replication. Mean separation was done using Fisher's protected least significant difference test with $P \leq 0.05$. Statistics for foliar disease severity were calculated on arcsin-transformed means; nontransformed means are reported in tables.

\section{Results and discussion}

In 2009, yields in hundred-weight per acre were significantly lower for 'Howden' than 'Camaro' and 'Aladdin', which were statistically similar (Table 1 ). In 2010, yields were significantly different for all three varieties, with Camaro yielding $260 \mathrm{cwt} / \mathrm{acre}$ and Howden producing $70 \mathrm{cwt} / \mathrm{acre}$. In 2009 , fruit per acre were significantly different between all varieties, with Camaro having 2760 fruit/acre and Howden having 1430 fruit/acre. In 2010, 'Camaro' had significantly more fruit per acre than 'Aladdin' and 'Howden', which were not significantly different. Average fruit weights were similar among varieties in 2009 , averaging $17.8 \mathrm{lb} /$ fruit (Table 1 ). However, in 2010 'Howden' fruit weighed $8.8 \mathrm{lb} /$ fruit, which was significantly less than 'Camaro' but not 'Aladdin', which averaged 12.1 and $10.8 \mathrm{lb} /$ fruit, respectively. In 2009, 'Howden' had significantly fewer cull fruit per acre than 'Aladdin' or 'Camaro', though in 2010 there were no differences. Because 'Howden' had significantly fewer fruit per acre in 2009 than the other varieties, it is not unexpected that cull fruit per acre would be less as well. These results indicate that variety had a significant impact on yield in both years of the trial.

There were no significant fungicide program by variety interactions for weight per acre, number of marketable fruit per acre, or average fruit weight in 2009 and 2010. In 2009, yields were not significantly affected by fungicide program, averaging 370 cwt/acre and 2160 fruit/acre for the two fungicide regimes and no-fungicide control. There was a significant interaction between fungicide program and variety for cull fruit per acre in 2009 (Table 2). Cull fruit were typically malformed or too small to be considered saleable. Loss of leaf area due to PM could have impacted cull fruit in both years. In 2009, cull fruit per acre decreased in 'Camaro' pumpkins grown in both fungicide programs compared with the no-fungicide control. However, cull fruit per acre in 'Howden' and 'Aladdin' were not significantly affected by fungicide program, averaging 110 and $380 \mathrm{cwt} /$ acre, respectively (Table 2 ). In 2010 , the main effects means for fungicide program were significantly different for fruit weight per acre and number of fruit per acre, but not for average fruit weight (Table 1). Cull fruit per acre were unaffected by any treatment in 2010. Main effects yields for fungicide program in 2010 increased from 130 to $190 \mathrm{cwt} /$ acre as fungicide treatments increased from the no-fungicide control to a high-input program (Table 1 ).

Yields were significantly less in the 2010 growing season than in 2009 (Table 1). Average commercial yields for 15- to 20-lb pumpkins in Kentucky are $220 \mathrm{cwt} /$ acre (Woods, 2008 ). Yields of all three varieties exceeded average expected commercial grower yields in 2009 , but in 2010 Aladdin and Howden yielded less than expected. The growing season in 2010 
Table 1. Main effects for mean yields, number of fruit and culls per acre, and average fruit weight for three pumpkin varieties grown under three fungicide spray programs in 2009 and 2010 in Lexington, KY.

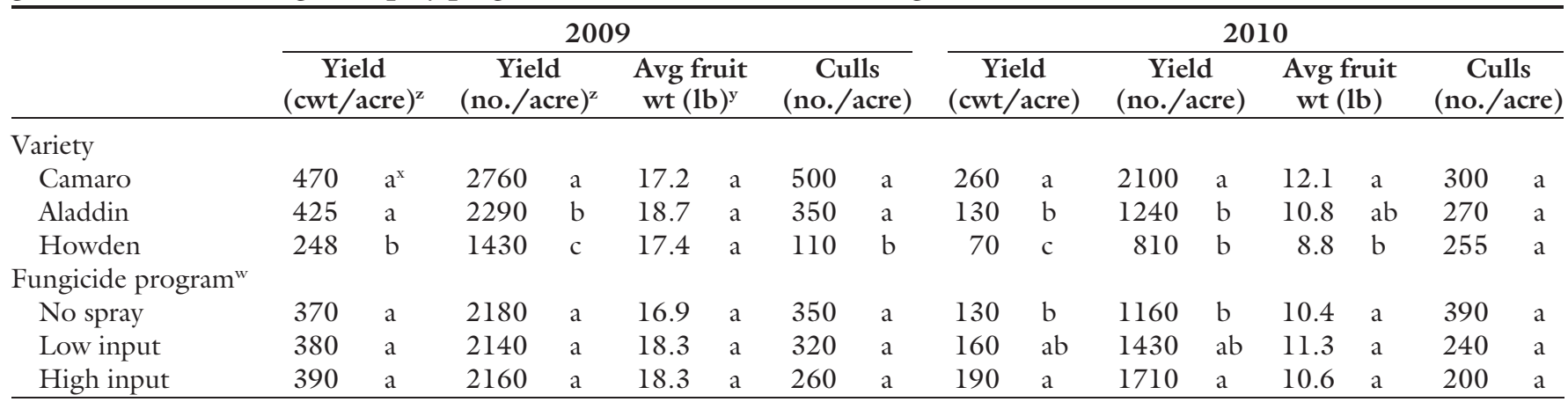

${ }^{2} 1 \mathrm{cwt} /$ acre $=112.0851 \mathrm{~kg} \cdot \mathrm{ha}^{-1} ; 1$ fruit $/$ acre $=2.4711$ fruit $/ \mathrm{ha}$

${ }^{y}$ Marketable pumpkins; $1 \mathrm{lb}=0.4536 \mathrm{~kg}$.

'Values in the same column for the same main effect (variety or spray program) followed by the same letter are not significantly different at $P \leq 0.05$ according to Fisher's protected least significant difference test.

w2009 and 2010 no spray $=$ no-spray control; 2009 and 2010 low input $=$ chlorothalonil applied at $1.5 \mathrm{lb} / \mathrm{acre}\left(\mathrm{l} .68 \mathrm{~kg} \cdot \mathrm{ha} \mathrm{a}^{-1}\right)$ on a 10 - $\mathrm{d} \mathrm{schedule} ; 2009$ high input $=$ myclobutanil applied at $2 \mathrm{oz} /$ acre $\left(140.1 \mathrm{~g} \cdot \mathrm{ha}^{-1}\right)$ alternated with chlorothalonil applied at $1.5 \mathrm{lb} /$ acre every $7 \mathrm{~d}$ and $2010 \mathrm{high}$ input $=$ myclobutanil applied at $2 \mathrm{oz} /$ acre alternated with chlorothalonil applied at $1.5 \mathrm{lb} /$ acre every $10 \mathrm{~d}$.

Table 2. Mean yields, number of fruit and culls per acre, and average fruit weight for three pumpkin varieties grown under three fungicide spray programs in 2009 and 2010 in Lexington, KY.

\begin{tabular}{|c|c|c|c|c|c|c|c|c|c|c|c|c|c|c|c|c|c|}
\hline \multirow{3}{*}{$\frac{\text { ty }}{\text { ro }}$} & \multirow{3}{*}{$\begin{array}{c}\begin{array}{c}\text { Fungicide } \\
\text { program }^{z}\end{array} \\
\text { No spray }\end{array}$} & \multicolumn{8}{|c|}{2009} & \multicolumn{8}{|c|}{2010} \\
\hline & & \multicolumn{2}{|c|}{$\begin{array}{c}\text { Yield } \\
(\mathrm{cwt} / \text { acre })^{y}\end{array}$} & \multicolumn{2}{|c|}{$\begin{array}{c}\text { Yield } \\
\text { (no./acre) }^{\mathrm{y}}\end{array}$} & \multicolumn{2}{|c|}{$\begin{array}{l}\text { Avg fruit } \\
\text { wt }(1 \mathrm{lb})^{\mathrm{x}}\end{array}$} & \multicolumn{2}{|c|}{$\begin{array}{c}\text { Culls } \\
\text { (no./acre) }\end{array}$} & \multicolumn{2}{|c|}{$\begin{array}{c}\text { Yield } \\
\text { (cwt/acre) }\end{array}$} & \multicolumn{2}{|c|}{$\begin{array}{c}\text { Yield } \\
\text { (no./acre) }\end{array}$} & \multicolumn{2}{|c|}{$\begin{array}{c}\text { Avg fruit } \\
\text { wt (lb) }\end{array}$} & \multicolumn{2}{|c|}{$\begin{array}{c}\text { Culls } \\
\text { (no./acre) }\end{array}$} \\
\hline & & 460 & $a^{w}$ & 2940 & $\mathrm{a}$ & 15.6 & $\mathrm{~b}$ & 710 & $\mathrm{a}$ & 220 & $a b c$ & 1770 & $a b$ & 12.5 & a & 280 & $\mathrm{a}$ \\
\hline Camaro & Low input & 470 & a & 2700 & $a b$ & 17.4 & $a b$ & 360 & $\mathrm{bc}$ & 260 & $a b$ & 2180 & a & 11.9 & $\mathrm{ab}$ & 180 & $\mathrm{a}$ \\
\hline Camaro & High input & 480 & a & 2600 & $a b$ & 18.6 & $\mathrm{ab}$ & 360 & $\mathrm{bc}$ & 280 & $\mathrm{a}$ & 2380 & $\mathrm{a}$ & 12.0 & $\mathrm{ab}$ & 200 & $\mathrm{a}$ \\
\hline Aladdin & No spray & 430 & a & 2290 & $a b c$ & 18.5 & $\mathrm{ab}$ & 270 & bcd & 77 & de & 910 & bcd & 10.1 & $\mathrm{abc}$ & 290 & $\mathrm{a}$ \\
\hline Howden & No spray & 220 & $\mathrm{c}$ & 1310 & $\mathrm{~d}$ & 16.7 & $\mathrm{ab}$ & 60 & $\mathrm{~d}$ & 50 & e & 590 & $\mathrm{~d}$ & 7.9 & c & 410 & $\mathrm{a}$ \\
\hline Howden & Low input & 220 & $\mathrm{c}$ & 1200 & $\mathrm{~d}$ & 18.8 & $\mathrm{ab}$ & 110 & $\mathrm{~cd}$ & 90 & de & 860 & $\mathrm{~cd}$ & 10.2 & $a b c$ & 270 & $\mathrm{a}$ \\
\hline Howden & High input & 310 & $\mathrm{bc}$ & 1800 & $\mathrm{~cd}$ & 17.0 & $\mathrm{ab}$ & 160 & $\mathrm{~cd}$ & 90 & de & 1000 & bcd & 8.7 & bc & 90 & $\mathrm{a}$ \\
\hline
\end{tabular}

${ }^{2} 2009$ and 2010 no spray $=$ no-spray control; 2009 and 2010 low input $=$ chlorothalonil applied at $1.5 \mathrm{lb} / \mathrm{acre}\left(1.68 \mathrm{~kg} \cdot \mathrm{ha}{ }^{-1}\right)$ on a 10 - $\mathrm{d} \mathrm{schedule;} 2009 \mathrm{high}$ input $=$ myclobutanil applied at $2 \mathrm{oz} /$ acre $\left(140.1 \mathrm{~g} \cdot \mathrm{ha}^{-1}\right)$ alternated with chlorothalonil applied at $1.5 \mathrm{lb} /$ acre every $7 \mathrm{~d}$ and 2010 high input $=$ myclobutanil applied at $2 \mathrm{oz} /$ acre alternated with chlorothalonil applied at $1.5 \mathrm{lb} /$ acre every $10 \mathrm{~d}$.

${ }^{\mathrm{y}} \mathrm{l} \mathrm{cwt} / \mathrm{acre}=112.0851 \mathrm{~kg} \cdot \mathrm{ha}{ }^{-1} ; \mathrm{l}$ fruit $/$ acre $=2.4711$ fruit $/ \mathrm{ha}$.

${ }^{x}$ Marketable pumpkins; $1 \mathrm{lb}=0.4536 \mathrm{~kg}$.

"Values in the same column for the same main effect (variety or spray program) followed by the same letter are not significantly different at $P \leq 0.05$ according to Fisher's protected least significant difference test.

was drier and warmer than that in 2009. Daily average air temperatures were 71.3 and $72.6^{\circ} \mathrm{F}$ in July and Aug. 2009 , respectively, but were 77.5 and $77.4{ }^{\circ} \mathrm{F}$ in July and Aug. 2010, respectively. High average daily temperatures can decrease yield potential in large-fruited crops such as pumpkin as respiration may be increased at the expense of yield (Rubatzky and Yamaguchi, 1997). Rainfall in 2010 was less than that in 2009 as well. Although the presence of irrigation minimized the impact of rainfall from a production standpoint, the research site experienced 17.8 inches of rain during the study period in 2009 and only 5.7 inches in 2010 (data not shown).

No interaction was noted between varieties and fungicide programs in
2009 for disease severity estimated through AUDPC; however, a significant interaction was found between main effects in 2010. In the 2009 trial, varieties differed significantly in their susceptibility to PM (Table 3), as was previously reported (Coolong and Seebold, 2008, 2009). Disease severity was lowest in 'Camaro', while 'Howden' and 'Aladdin' exhibited similarly high levels of disease. AUDPC values for 'Howden' were more than twice that of 'Camaro'. The effect of fungicides was greatest on the PMsusceptible 'Howden' and moderately resistant 'Aladdin'. For these varieties, no difference was observed between the untreated control and the chlorothalonil 10-d (low input) program. However, chlorothalonil alternated with myclobutanil (high-input program) resulted in a $40 \%$ to $50 \%$ reduction in PM severity. No significant differences in disease were observed between any fungicide treatment and the untreated control on 'Camaro' (Table 4). In 2010, overall disease pressure was lower than in the previous year, and varieties responded similarly to PM as in 2009. In 2010, 'Camaro' had the lowest AUDPC and the high-input fungicide program appeared to have the greatest impact on reducing PM severity (Table 4 ). The high-input program significantly reduced disease severity on all three varieties, providing a $50 \%$ to $60 \%$ reduction in PM severity. Untreated 'Camaro' had significantly less PM than 'Howden' or 'Aladdin' treated with the high-input program. No 
significant differences in disease were observed between the low- or high-input programs for 'Camaro' (Table 4).

It is interesting that there were no significant fungicide program by variety interactions for pumpkin yield

Table 3. Main effects for severity of powdery mildew $(P M)$ on three pumpkin varieties grown under three fungicide spray programs in 2009 and 2010 in Lexington, KY.

\begin{tabular}{lrlrr}
\hline & \multicolumn{2}{c}{ PM severity (AUDPC) } \\
\cline { 2 - 5 } & 2009 & 2010 \\
\hline Variety & & & & \\
Camaro & 893 & b $^{y}$ & 269 & b \\
Aladdin & 1722 & a & 1183 & a \\
Howden & 1930 & a & 1480 & a \\
Fungicide & & & & \\
$\quad$ program & \\
No spray & 1894 & a & 1275 & a \\
Low input & 1611 & a & 912 & b \\
High input & 1040 & b & 607 & c \\
\hline
\end{tabular}

${ }^{\text {2}} \mathrm{PM}$ severity: overall (season-long) severity of powdery mildew as determined by the area under disease progress curves (AUDPCs) calculated from severity ratings taken on 15 Aug., 22 Aug., 30 Aug., 7 Sept., and 18 Sept. 2009 and 23 July, 17 Aug., 25 Aug., 2 Sept., and 10 Sept. 2010.

"Means in the same column followed by the same letter do not differ significantly as determined by Fisher's protected least significant difference test $(P \leq 0.05)$. Statistics for foliar disease severity were calculated on arcsin-transformed means; nontransformed means are reported in the table.

$\times 2009$ and 2010 no spray $=$ no-spray control; 2009 and 2010 low input $=$ chlorothalonil applied at $1.5 \mathrm{lb} /$ acre $\left(1.68 \mathrm{~kg} \cdot \mathrm{ha}^{-1}\right)$ on a $10-\mathrm{d}$ schedule; and 2009 high input $=$ myclobutanil applied at $2 \mathrm{oz} /$ acre $\left(140.1 \mathrm{~g} \cdot \mathrm{ha}^{-1}\right)$ alternated with chlorothalonil applied at $1.5 \mathrm{lb} /$ acre every $7 \mathrm{~d}$ and 2010 high input $=$ myclobutanil applied at $2 \mathrm{oz} /$ acre alternated with chlorothalonil applied at $1.5 \mathrm{lb} /$ acre every $10 \mathrm{~d}$

Table 4. Severity of powdery mildew (PM) on pumpkin varieties grown under three fungicide spray programs in 2009 and 2010 in Lexington, KY.

\begin{tabular}{lcrlrl}
\hline & & \multicolumn{3}{c}{ PM severity (AUDPC) } \\
\cline { 3 - 6 } Variety & Fungicide program & \multicolumn{2}{c}{ 2009 } & 2010 \\
\hline Camaro & No spray & 909 & $\mathrm{de}^{\mathrm{x}}$ & 358 & $\mathrm{~d}$ \\
Camaro & Low input & 1117 & $\mathrm{de}$ & 268 & $\mathrm{de}$ \\
Camaro & High input & 654 & $\mathrm{e}$ & 179 & $\mathrm{e}$ \\
Aladdin & No spray & 2332 & $\mathrm{ab}$ & 1667 & $\mathrm{ab}$ \\
Aladdin & Low input & 1745 & $\mathrm{bc}$ & 1195 & $\mathrm{ab}$ \\
Aladdin & High input & 1087 & $\mathrm{de}$ & 686 & $\mathrm{c}$ \\
Howden & No spray & 2443 & $\mathrm{a}$ & 1975 & $\mathrm{a}$ \\
Howden & Low input & 1969 & $\mathrm{abc}$ & 1392 & $\mathrm{ab}$ \\
Howden & High input & 1379 & $\mathrm{~cd}$ & 1074 & $\mathrm{bc}$ \\
\hline
\end{tabular}

z2009 and 2010 no spray = no-spray control; 2009 and 2010 low input = chlorothalonil applied at $1.5 \mathrm{lb} / \mathrm{acre}$ $\left(1.68 \mathrm{~kg} \cdot \mathrm{ha}^{-1}\right)$ on a 10 -d schedule; and 2009 high input = myclobutanil applied at $2 \mathrm{oz} / \mathrm{acre}\left(140.1 \mathrm{~g} \cdot \mathrm{ha}^{-1}\right)$ alternated with chlorothalonil applied at $1.5 \mathrm{lb} /$ acre every $7 \mathrm{~d}$ and 2010 high input = myclobutanil applied at $2 \mathrm{oz} /$ acre alternated with chlorothalonil applied at $1.5 \mathrm{lb} /$ acre every $10 \mathrm{~d}$.

YPM severity: overall (season-long) severity of powdery mildew as determined by the area under disease progress curves (AUDPCs) calculated from severity ratings taken on 15 Aug., 22 Aug., 30 Aug., 7 Sept., and 18 Sept. 2009 and 23 July, 17 Aug., 25 Aug., 2 Sept., and 10 Sept. 2010.

'Means in the same column followed by the same letter do not differ significantly as determined by Fisher's protected least significant difference test $(P \leq 0.05)$. Statistics for foliar disease severity were calculated on arcsintransformed means; nontransformed means are reported. fruit was affected by fungicide program in 'Magic Lantern', but not 'Howden' (Wyenandt et al., 2008).

Our results suggest that in 2009 , although wetter than average for Kentucky, variety selection had a significant impact on yield while fungicide program did not. In 2010, a hotter and drier season, both fungicide program and variety selection impacted yield. Nonetheless, results suggest that 'Camaro', with high cucurbit PM resistance and high yield potential, performed adequately with no fungicides applied in 2009 and 2010. This indicates that growers can significantly reduce chemical inputs through judicious variety selection. Differences in yield for the varieties tested were likely due to other factors (vigor) in addition to PM resistance. Selection for disease resistance can decrease yield potential compared with nonresistant selections in the absence of disease (Staub and Grumet, 1993). McGrath and Staniszewska (1996) reported varieties of a PM-resistant summer squash variety having greater yield potential than a nonresistant variety. McGrath (2002) also reported lower yields in a high PM-resistant variety of winter squash than a moderately resistant variety. It is clear that although cucurbit PM resistance will affect yields, particularly in the presence of disease, genetic predisposition for yield potential is also an important consideration. This data suggests that a high-resistance variety significantly reduced the need for cucurbit PM fungicides during times of moderate disease pressure. In years or locations that favor higher levels of PM, reduced or no fungicide inputs may suffice to acceptably control disease while maintaining yields. When varieties with little or no resistance to PM are planted, a protectant fungicide such as chlorothalonil plus a PM-specific fungicide will be required to provide adequate suppression of disease.

\section{Literature cited}

Bachi, P.R., J.W. Beale, J.R. Hartman, D.E. Hershman, S.J. Long, K.W. Seebold, and P. Vincelli. 2010. Plant diseases in Kentucky: Plant disease diagnostic laboratory summary 2010. Univ. Kentucky Coop. Ext. Serv. Bul.

Canaday, C., A.L. Wszelaki, J.S. Reeves, and R.C. Dunagan. 2009. Evaluation of pumpkin cultivars and lines for powdery 
mildew resistance in west Tennessee, 2008. Plant Dis. Mgt. Rpt. 3:V051.

Cohen, R., A. Hanan, and H.S. Paris. 2003. Single-gene resistance to powdery mildew in zucchini squash (Cucurbita pepo). Euphytica 130:433-441.

Coolong, T. and K. Seebold. 2008. Evaluation of powdery mildew tolerance in pumpkin in central Kentucky, p. 47-50. In: 2008 Fruit and vegetable research report. Univ. of Kentucky Coop. Ext. Serv. Bul. PR-572.

Coolong, T. and K. Seebold. 2009. Evaluation of powdery mildew tolerance in pumpkin in central Kentucky, p. 41-43. In: 2009 Fruit and vegetable research report. Univ. of Kentucky Coop. Ext. Serv. Bul. PR-603.

Cushman, K.E., W.B. Evans, D.M. Ingram, P.D. Gerard, R.A. Straw, C.H. Canaday, J.E. Wyatt, and M.M. Kenty. 2007. Reduced foliar disease and increased yield of pumpkin regardless of management approach or fungicide combinations. HortTechnology 17:56-61.

Jahn, M., H.M. Munger, and J.D. McCreight. 2002. Breeding cucurbit crops for powdery mildew resistance, $\mathrm{p}$. 239-248. In: R.R. Belanger, W.R. Bushnell, A.J. Dik and T.L.W. Carver (eds.). The powdery mildews a comprehensive treatise. APS Press, St. Paul, MN.

James, R.V. and W.R. Stevenson. 2005. Evaluation of pumpkin and squash varieties for resistance to powdery mildewHancock, WI, 2004. Biol. Cult. Tests Control Plant Dis. 20:V005.

James, R.V. and W.R. Stevenson. 2006. Evaluation of pumpkin and squash varieties for resistance to powdery mildewHancock, WI, 2005. Biol. Cult. Tests Control Plant Dis. 21:V012.

Keinath, A.P. and V.B. DuBose. 2000. Evaluation of pumpkin varieties for powdery and downy mildew resistance, virus tolerance, and yield. HortScience 35: 281-285.
Koike, S.T., P. Gladders, and A.O. Paulus. 2007. Vegetable diseases a color handbook. Academic Press, Boston, MA.

Lebeda, A., M.T. McGrath, and B. Sedlakova. 2010. Fungicide resistance in cucurbit powdery mildew fungi, p. 221-246. In: O. Carisse (ed.). Fungicides. InTech, Rijeka, Croatia.

McGrath, M.T. 2001. Fungicide resistance in cucurbit powdery mildew: Experiences and challenges. Plant Dis. 85:236-245.

McGrath, M.T. 2002. Efficacy of genetic control, used alone and combined with fungicides, for managing powdery mildew in winter squash, 2001. Biol. Cult. Tests Control Plant Dis. 17:V022.

McGrath, M.T. 2004. Managing powdery mildew in winter squash with genetic control and chemical control. Phytopathology 94:S165. (Abstr.).

McGrath, M.T. 2006. Occurrence of fungicide resistance in Podosphaera xanthii and impact on controlling cucurbit powdery mildew in New York, p. 473-482. In: G.J. Holmes (ed.). Procedings of Cucurbitaceae 2006. Universal Press, Raleigh, NC.

McGrath, M.T. and H. Staniszewska. 1996. Management of powdery mildew in summer squash with host resistance, disease threshold-based fungicide programs, or an integrated program. Plant Dis. 80:1044-1052.

McGrath, M.T. and N. Shishkoff. 2003. First report of the cucurbit powdery mildew fungus (Podosphaera xanthii) resistant to strobilurin fungicides in the United States. Plant Dis. 87:1007.

McGrath, M.T. and J.F. Davey. 2006. Comparison of powdery mildew resistant pumpkin under a reduced-fungicide program, 2005. Biol. Cult. Tests Control Plant Dis. 21:V021.

Perez-Garcia, A., D. Romero, D. FernandezOrtuno, F. Lopez-Ruiz, A. DeVicente, and J.A. Tores. 2009. The powdery mildew fungus Podosphaera fusca (synonym Podosphaera xanthii), a constant threat to $\mathrm{cu}^{-}$ curbits. Mol. Plant Pathol. 10:153-160.
Rubatzky, V.E. and M. Yamaguchi. 1997. World vegetables: Principles, production, and nutritive values, 2 nd ed. Chapman and Hall, New York.

Schroeder, W.T. and R. Provvidenti. 1969. Resistance to benomyl in powdery mildew of cucurbits. Plant Dis. Rptr. 53: 271-275.

Shaner, E. and R.E. Finney. 1977. The effect of nitrogen fertilization on the expression of slow-mildewing resistance in Knox wheat. Phytopathology 67: 1051-1056.

Staub, J.E. and R. Grumet. 1993. Selection for multiple disease resistance reduces cucumber yield potential. Euphytica 67: 205-213.

University of Kentucky. 2011. Lexington, Kentucky Climate Data. 6 Apr. 2011. <http://wwwagwx.ca.uky.edu/cgi-bin/ ky_clim_data_www.pl>.

U.S. Department of Agriculture. 2011. Vegetable 2010 Summary. 8 Apr. 2011. <http://usda.mannlib.cornell.edu/ usda/current/VegeSumm/VegeSumm01-27-2011.pdf>.

Woods, T. 2008. 2008 Vegetable and Melon Budgets. 4 Apr. 2011. <http:// www . uky . edu / A g / C D B REC / vegbudgets08.html>.

Woods, T. 2010. 2010 Kentucky produce planting and marketing intentions grower survey and outlook. Univ. of Kentucky Coop. Ext. Serv. Bul. AEC-2010-05.

Wyenandt, C.A., N. Maxwell, and D.L. Ward. 2008. Fungicide programs affect "practical" resistance development in cucurbit powdery mildew of pumpkin. HortScience 43:1838-1845.

Wyenandt, C.A., D.L. Ward, and N.L. Maxwell. 2010. Determining "practical" fungicide resistance development and drift in the control of cucurbit powdery mildew in pumpkin. Plant Health Prog, doi: 10.1094/PHP-2010-1122-02-RS.

Zitter, T.A., D.L. Hopkins, and C.E. Thomas. 1996. Compendium of cucurbit diseases. APS Press, St. Paul, MN. 